\title{
人工骨頭置換術に打ける骨セメント 固定法の有用性飞ついて
}

\author{
島根医大 整形外科
}

高田晃平・都谷治利

廣谷速人

\section{Prosthetic Replacement With and Without Cement in Femoral Neck Fractures}

by

\section{Kohei Takata, Harutoshi Ogai and Hayato Hirotani}

Department of Orthopaedics, Shimane Medical

School, lzumo

\begin{abstract}
Twenty-nine patients had a Moore hip endoprosthesis during the period from October 1979 to April 1984. Average follow-up period was 21 months (range: 2 to 54 months). In 11 patients, endoprosthsis with cement was performed with satisfactory clinical results, especially in relation to pain relief and weight bearing ambulation. X-ray examinations revealed no upper migration and loosening. In eighteen patients, endoprosthesis without cement was performed. Nine patients complained of pain $(50 \%)$. From roentgenograms, an increased tendency of loosening of the prosthesis was found in cases without cement.
\end{abstract}

高齢者の大腿骨頸部内側骨折の治療法として人工骨 頭置換術はひろく行なわれており，その術後成績む良 好である．従来人工骨頭は self locking type ${ }^{8)}$ の ものが一般に使用されていたが，術直後より確実な anchoring を得るために骨セメントによる固定法3) が行なわれるようになった.

今回，島根医大整形外科にて人工骨頭置換術を行っ た症例について，セメント使用および非使用による術 後成績の差異について比較検討しここに報告する.

症例

昭和 54 年 10 月島根医大整形外科開設以来経験した 大腿骨頸部内側骨折は 36 例である. そのうち人工骨 頭置換術を行ったものは29例（男 2 例，女 27 例）, 29 関節で，年齢は 63 歳 90 歳（平均 77.3 歳）であ る。骨セメント使用例は11例で, ceramic ball を 使用した Moore 型 narrow stem を多く用い，骨 セメント非使用例は 17 例で， Moore 型 standard stem を用いた. 受傷より手術までの期間は平均 16
日で，最長 4 力月を経過したものあある.

原疾患としては老人性痴呆 6 例, 片麻痻 3 例, パー キンソニスム，関節リウマチ，悪性リンパ腫および骨 軟化症各 1 例である。

骨粗鬆症は全例にみられたが，Singh index ${ }^{10)}$ に よる分類では 5 度 3 例， 4 度 9 例， 3 度 11 例， 2 度 5 例および 1 度 1 例であった。

術後観察期間は 2 か月より 4 年 6 か月で，セメント 使用例の平均観察期間は 10 か月，セメント非使用例 では 33 か月である，術後死亡例は 2 例である。

結果

術後起立開始時期はセメント使用例は平均 7 日, 非 使用例は20日で，セメント使用例が短く，起立開始 時に股関節痛を訴えたものはそれぞれ 2 例 $(18 \%)$ と 9 例 $(50 \%)$ で，最終診察日に股関節痛を訴えたもの 屯それぞれ 1例 $(9 \%)$ と6例 $(33 \%)$ であり，セメ ント使用例に股関節痛の発生は少ない。

術後の可動域に関してはセメント使用群と非使用例 
表 1 Radiological Evaluations

\begin{tabular}{ll|c|c|c|c}
\hline & & upper migration & distal migration & radiolucency & sclerosis \\
\hline with cement & (11) & 0 & 0 & 0 & 0 \\
without cement & (18) & 1 & 7 & 3 & 8
\end{tabular}

で屈曲がそれぞれ平均 $80^{\circ}$ と $86^{\circ}$ ，外転がそれぞれ平 均 $24^{\circ}$ であり, 両者に差異はみられなかった。

歩行能力を日整会変形性股関節症評価表により評価 するとセメント使用例 5.6 点, 非使用例 7.5 点であっ た.

合併症としては深部感染 1 例, 脱臼 2 例および upper migration 1 例であった. 深部感染例はセメ ント固定をした症例であるが，元疾患として悪性りン 八゚腫があり，免度学的異常が考えられた症例である。 持続洗浄にて炎症所見は消失し, 疼痛なく 1 本杖歩行 が可能である. Upper migration をきたした症例は セメント非使用例である. 術後 1 年 8 力月で股関節痛 をきたし，X線像にて upper migration と distal migration がみられ，人工股関節置換術を行った. 術後経過は良好で股関節痛はない。

術後のX線所見では人工骨頭の upper migration, distal migration, stem 周囲の透明帯および stem 先端部の骨硬化像はセメント使用例にはみられなかっ たが，セメント非使用例では表 1 のような結果がえら 机た。

\section{考察}

大腿骨頸部内側骨折の治療法として人工骨頭置換術 は広く行なわれ，Moore 型や Thompson 型の骨頭 が多く用いられている. 人工骨頭の大腿骨への固定法 としては self locking8) によるあのとセメントによ る固定法3) がある。セメント固定による人工骨頭置換 術は高度の骨粗鬆症，病的骨折，SLE などによる大 腿骨骨頭の無腐性壊死で長期の余命が期待できないも のおよびパーキンソニスムや老人性痴呆などの精神疾 患等の原疾患をもつあのに適応がある ${ }^{4)}$ とされてい る. Beckenbaugh ら1)は新鮮骨折に対しても一次的 にセメント固定による人工骨頭置換術が適応であると 述べている.

われわれ自根医大整形外科開設以来 3 年間はセメ ント非使用による人工骨頭置換を行ってきたが，その 後はセメントを使用した固定法を行っている，術後成
績は起立開始時期，起立開始時の股関節痛に対しては セメント固定法によるあのがよかったが，可動域や歩 行能力に関しては両者に差異は認められ就った。 術後の X 線像でも表 1 の如く, セメント固定例には upper migration, distal migration, stem 周囲の 透明帯抢よび stem 先端の骨硬化像はみられなかっ たが，セメント固定例ではそれぞれ 1 例， 7 例， 3 例 および8例に異常がみられた。

人工骨頭置換術におけるセメント使用の有無は術後 成績を左右する重要学因子である。セメント固定を行 ったあのでは術直後より起立歩行が可能1)で, distal migration の発生も防止できる ${ }^{5)}$. 術後の疼痛，歩 行能力の低下扰よび社会的な不自由が残るすのはセx ント使用例に少なく，セメント固定の有用性について の報告911) がみられる. Welch ら ${ }^{11)}$ は術後の死亡率 はセメント非使用例で $21 \%$ ，セメント使用例で $7 \%$ であると述べており，生命の予後に関してもセメント 固定は良好である。

一方, Hunter ら $^{6)}$ は術後成績はセメント使用, 非 使用の両者の間に差異はみられず，セメント固定はパ ーキンソニスム，精神疾患に限定すべきであると報告 している.

合併症としては感染, 脱臼, upper migration distal migration などがあるが，感染と脱曰に関し てはセメント使用抢よび非使用の両者の間に差異は認 められな( ${ }^{7) 11)}$ 。 セメントを使用したあのは非使用例 より約 2 倍の荷重に耐え, 強固である2) 反面, 毛蓋関 節軟骨の摩耗がおこりやすく, upper migration の 原因と屯考えられる ${ }^{4)}$. しかしセメント固定が臼蓋関 節軟骨へおよぼす影響は明確には究明されていない4)， セメント固定による人工骨頭置換に打ける upper migration に関しては Evert ら3) が8\% に発生し たとし，Gingras ら4) はまったくなかったと述べてお りセメント非使用例と比較しても多くはない，Distal migration はセメント非使用例では高頻度に発生す るが，セメント固定をしたものではみられない5)。

セメンへ使用による人工骨頭置換術は早期起立歩行 
が可能で, 疼痛や歩行能力の低下屯少なく高齢者の大 腿骨頸部骨折の治療法として有用であると考える.

結 語

1）島根医大整形外科において経験した大腿骨頸部 内側骨折に対する 29 例の人工骨頭置換術の術後成績 をセメント使用 (11 例) および非使用 (18例) 群につ いて比較検討した.

2）術後臨床成績およびX 線検査所見ともセメント 使用群が良好であった。

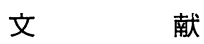

1) Beckenbaugh, R. D., Tressler, H. A., Johnson, E. W. Jr.: Results after hemiarthroplasty of the hip using a cemented femoral prosthesis. Mayo Clin. Proc. 52: 349-353, 1977.

2) Buerkle, A. R., Eftekhar, N. S.: Fixation of the femoral head prosthesis with methylmethacrylate. Clin. Orthop. 111: 134-141, 1975.

3) Evarts, C. M. : Endoprosthesis as the primary treatment of the femoral neck fractures. Clin. Orthop. 92: 69-76, 1973.

4) Gingras, M. B., Clarke, J., Evarts, C. M. : Prosthetic replacement in femoral neck fractures. Clin. Orthop. 152: 147-157, 1980.

5) Gristina, A. J., Klein, A., Rovere, G. D. et al.: Long-term periprosthetic roentgenographic changes after Austin Moore endoprosthetic replacement. Orthop. Trans. 7: 401-402, 1983.

6) Hunter, G. A.: Should we abandon primary prosthetic replacement for fresh displaced fracture of the neck of the femur ? Clin. Orthop. 152: 158-161, 1980.

7) Lausten, G. S., Vedel, P.: Cementing v. not cementing the Monk endoprosthesis.
Injury 13: 484-488, 1982.

8) Moore, A. T.: The self-locking metal hip prosthesis. J. Bone Joint Surg. 39-A: 811-827, 1957.

9) Sonne-Holms, S., Walter, S., Jensen, J. S. : Moore hemi-arthroplasty with and without bone cement in femoral neck fractures. Acta Orthop. Scand. 53: 953956, 1982.

10) Singh, M., Nagrath, A. R., Maini, P. S.: Changes in trabecular pattern of the upper end of the femur as an index of osteoporosis. J. Bone. Joint Surg. 52-A : 457-467, 1970.

11) Welch, R. B., Taylor, L. W., Wynne, G. F. et al.: Results with the cemented hemiarthroplasty for displaced fractures of the femoral neck. In the Hip. Proceedings of the fifth open scientific meeting for the hip society, Mosby, St. Louis, 1977.

\section{追 加 山口県立中央病院 弓削大四郎}

1） 1978 年 フランス整形災害外科学会 で人工骨頭 置換に関するシンポジゥムが行われ，1979年の Reove de chirurgie orthopédiques に23頁にわ たる論文が発表されているが， 1,800 例の術後 6 ケ月 以上の遠隔成績では, Thompson 型人工骨頭をセメ ント固定したあのが最もよいという報告があってい て，演者の報告と同じ内容である.

2）岩崎先生に対する返事

Subcapital の骨折には最近 Bicentric の人工骨 頭（セメントあるいは非セメント）を使用している が，その他大腿骨頭部骨折には Judet の Pedicle Bone-Grafting を主としてやっている. AustinMoore の人工骨頭置換を今迄に 80 例 近く行ったが, 術後無痛な症例は $65 \%$ 位にすぎない。 